\title{
Effectiveness of Photocatalytic Decolourization of Reactive Red 120 Dye in Textile Effluent Using $\mathrm{UV} / \mathrm{H}_{2} \mathrm{O}_{2}$
}

\author{
Rishi Ananthashankar and Abdel Ghaly \\ Department of Process Engineering and Applied Science, \\ Faculty of Engineering, Dalhousie University, Halifax, Canada
}

Received 2013-06-28, Revised 2013-08-12; Accepted 2013-08-16

\begin{abstract}
The effectiveness of Advanced Oxidation Process (AOP) for degradation of reactive red 120 dye in aqueous solutions was tested in this present study. Ten different concentrations of the reactive red 120 dye were exposed to $\mathrm{UV}$ alone and a combination of $\mathrm{UV}$ with two different concentrations $(10 \mathrm{ml} / \mathrm{L}$ and $20 \mathrm{ml} / \mathrm{L})$ of $\mathrm{H}_{2} \mathrm{O}_{2}$ for 10 different retention times at the $\mathrm{pH}$ of textile effluent $(\mathrm{pH}=10-11)$. The effect of acidifying the dye solution on the removal efficiency was also investigated. The COD removal efficiency was determined for the most efficient treatment. The dye degradation efficiency obtained after $60 \mathrm{~min}$ exposure to UV alone was $27.01 \%$ for $50 \mathrm{mg} / \mathrm{L}$ dye concentration and $0.33 \%$ for $500 \mathrm{mg} / \mathrm{L}$ dye concentration. The degradation efficiency obtained after exposure to $\mathrm{UV} / 10 \mathrm{ml} / \mathrm{L} \mathrm{H}_{2} \mathrm{O}_{2}$ was $99.83 \%$ after $25.4 \mathrm{~min}$ for the $50 \mathrm{mg} / \mathrm{L}$ dye concentration and $99.70 \%$ after $60 \mathrm{~min}$ for the $500 \mathrm{mg} / \mathrm{L}$ dye concentration. Exposure to UV/ $20 \mathrm{ml} / \mathrm{L} \mathrm{H}_{2} \mathrm{O}_{2}$ resulted in a degradation efficiency of $99.96 \%$ after $20 \mathrm{~min}$ for the $50 \mathrm{mg} / \mathrm{L}$ dye concentration and $99.95 \%$ after 60 min for the $500 \mathrm{mg} / \mathrm{L}$ dye concentration. Increasing the $\mathrm{H}_{2} \mathrm{O}_{2}$ from $10 \mathrm{ml} / \mathrm{L}$ to $20 \mathrm{ml} / \mathrm{L}\left(\mathrm{UV} / 20 \mathrm{ml} / \mathrm{L} \mathrm{H}_{2} \mathrm{O}_{2}\right)$ improved the oxidation efficiency and reduced the treatment time. The Chemical Oxygen Demand (COD) analysis performed on the effluent obtained from the UV/20 ml/L $\mathrm{H}_{2} \mathrm{O}_{2}$ treatment showed a COD removal efficiency of $99.96 \%$ (from $704 \mathrm{mg} / \mathrm{L}$ to $416 \mathrm{mg} / \mathrm{L}$ ) after $20 \mathrm{~min}$ for the $50 \mathrm{mg} / \mathrm{L}$ dye concentration and $99.95 \%$ (from $1184 \mathrm{mg} / \mathrm{L}$ to $256 \mathrm{mg} / \mathrm{L}$ ) after $60 \mathrm{~min}$ for the $500 \mathrm{mg} / \mathrm{L}$ dye concentrations. However the final COD concentrations were higher than the COD discharge limit of $80 \mathrm{mg} / \mathrm{L}$. The COD discharge limit of $80 \mathrm{mg} / \mathrm{L}$ could be achieved with UV/ $20 \mathrm{ml} / \mathrm{L} \mathrm{H}_{2} \mathrm{O}_{2}$ treatment by increasing the exposure time (longer than $60 \mathrm{~min}$ ). The $\mathrm{pH}$ of the treated effluent is within the accepted discharge limit of 6-9. Treatment of the dye effluent under acidic condition was slightly faster but the time reduction does not justify the cost of chemicals addition to adjust the $\mathrm{pH}$ to 3 before treatment and then to 7 and the further treatment to remove these chemicals before disposal.
\end{abstract}

Keywords: Textiles, Waste Waters, Dyes, Reactive Red 120, UV, $\mathrm{H}_{2} \mathrm{O}_{2}, \mathrm{UV} / \mathrm{H}_{2} \mathrm{O}_{2}$, Exposure Time

\section{INTRODUCTION}

The textile industry is one of the oldest and largest industries in the world. It contributes significantly towards the economic growth of textile producing countries by providing employment with no skills thereby increasing the Gross Domestic Product (GDP) of these countries (Gereffi, 2002; Keane and Velde, 2008). China, India, Hong Kong, USA and Mexico are the top five textile producers with world shares of $50,15,6,5$ and $3 \%$, respectively (Fashion Products, 2012). Textile industries uses large amount of water for processing textile products Atif (2002) reported that a typical textile industry in Pakistan manufactures 12-20 tonnes of textiles per day and uses $1,000-3,000 \mathrm{~m}^{3}$ of water/day $\left(60-80 \mathrm{~m}^{3} / \mathrm{t}\right)$. This amount may vary depending on the type of textile produce and the size of production facility.

The textile industries also use significant amounts of dyes and chemicals. Kant (2012) stated that a normal sized textile industry uses about $0.51-0.58 \mathrm{~kg}$ of

Corresponding Author: Abdel Ghaly, Department of Process Engineering and Applied Science, Faculty of Engineering, Dalhousie University, Halifax, Canada 
chemicals per $\mathrm{m}^{3}$ of water per day. Significant portions of the textile dyes are found in a high concentration in textile effluents due to the large amount of unfixed dyes on the fabrics that gets washed away during the textile finishing processes. According to Dyes and Pigments (2010), approximately $2-40 \%$ of dyes are washed away depending on the type of fabric manufactured. Eswaramoorthi et al. (2008) reported that textile effluents have a $\mathrm{pH}$ in the range of $6-10$, a $\mathrm{BOD}$ in the range $80-6,000 \mathrm{mg} / \mathrm{L}$ and a COD in the range of $150-12,000$ $\mathrm{mg} / \mathrm{L}$. The characteristics of the effluents may differ according to the type of textile manufactured. Because of the high concentration of chemicals, textile effluents can cause environmental problems if not treated properly.

The high concentrations of chemicals in textile effluents are capable of harming the environment and human health. Laxman (2009) reported that textile effluents are capable of preventing photosynthesis of aquatic plants by blocking the penetration of sunlight into water. Nese et al. (2007) stated that textile effluents could prevent the growth of aquatic organisms by increasing the COD/BOD content of the receiving and depleting dissolved oxygen. Prolonged exposure to textile dyes can cause dermatitis, ulceration of skin, irritation of lungs and skin, headaches, nausea and even cancer in some of the cases have been reported (Mathur et al., 2005; Jain et al., 2003; Nese et al., 2007)

Several treatments are employed to remove contaminant from textile effluents. Suspended solids in textile effluents are removed by primary treatments such as coagulation, sedimentation and screening (EPA, 2003). The BOD, COD and organic substances in the effluent are removed by secondary treatment mechanisms including activated sludge, aerated lagoons and trickling filters (Lafond, 2008; Das, 2000). Dissolved salts and metal ions are removed using tertiary treatment processes such as electrodialysis or reverse osmosis (Babu et al., 2007; Das, 2000). However, these primary, secondary and tertiary treatment processes were found to be ineffective as some of the textile dyes are complexly structured and are nearly impossible to be degraded by these methods (Ghoreishi and Haghighi, 2003).

The Advanced Oxidation Process (AOPs) is a new and an efficient treatment for the removal of almost all solid components in textile effluents. A maximum of $42 \%$ COD removal from textile effluents can be achieved by biological treatment while upto $72 \%$ COD removal form effluent can be achieved with AOP (Montano, 2007; Rodriguez, 2003). AOP has the ability to take place under any temperature or pressure without the production of secondary components or sludge.
AOPs make use of oxidants like UV, $\mathrm{O}_{3}, \mathrm{H}_{2} \mathrm{O}_{2}, \mathrm{Fe}^{2+}$, $\mathrm{TiO}_{2}$, ultra sound and electron beam irradiation to generate $\mathrm{OH}^{\circ}$ radicals, which have the potential to oxidize the organics in the effluents (Stasinakis, 2008; Gogate and Pandit, 2004). These $\mathrm{OH}^{\circ}$ radicals: (a) have an oxidizing potential of $2.33 \mathrm{~V}$ (Kdasi et al., 2004), (b) have an affinity towards electrons in the system and hence are called electrophiles and (c) have one unpaired electron on its outer shell which makes them unstable and as such try to attain a more stable configuration by reacting with the organics (Munter, 2001).

\section{OBJECTIVE}

The aim of the study was to investigate the degradation efficiency of the reactive red 120 (HE3B) dye by an Advanced Oxidation Process (AOP). The specific objectives were to: (a) to study the effect of UV alone on the degradation of varying dye concentrations $(50-500 \mathrm{mg} / \mathrm{L})$ at a $\mathrm{pH}$ of 10.5 (b) to study the effect of $\mathrm{UV} / \mathrm{H}_{2} \mathrm{O}_{2}$ (using 10 and $20 \mathrm{ml} / \mathrm{L} \quad \mathrm{H}_{2} \mathrm{O}_{2}$ ) on the degradation of varying dye concentrations (50-500

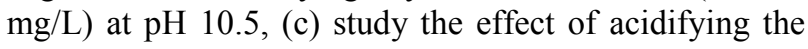
dye solution to $\mathrm{pH} 3$ on the degradation efficiency and (d) determine the Chemical Oxygen Demand (COD) removal efficiency for the best treatment process.

\section{MATERIALS AND METHODS}

\subsection{Experimental Apparatus}

A custom build photooxidation system (Figure 1) was used in the experiments. The system consists of a photoreactor, an influent feeding tank, a peristaltic pump and an effluent collection tank. The photoreactor was made up of stainless steel with an inner and an outer diameter of 55 and $61 \mathrm{~mm}$, respectively. The total working volume of the photoreactor was $840 \mathrm{ml}$ (Figure 2). A $448 \mathrm{~mm}$ long and $0.85 \mathrm{~mm}$ thick stainless steel coil (Figure 3) was placed inside the photoreactor to ensure uniform mixing and exposure of the effluent to UV by creating turbulence. A low pressure mercury lamp (Trojan UV, 3020, Ontario, Canada) enclosed in a 21 $\mathrm{mm}$ diameter quartz tube and emitting UV light (380 $\mathrm{nm})$ was inserted into the center of the reactor.

The feeding tank was a $20 \mathrm{~cm}$ in diameter cylinder made of Poly Vinyl Chloride (PVC) with a working volume of $12 \mathrm{~L}$. The container had $4 \mathrm{~mm}$ thick Plexiglas ${ }^{\mathrm{TM}}$ (Poly Methyl Methacrylate) detachable top which had a $4 \mathrm{~mm}$ diameter opening to equalize the pressure difference inside the container caused by pumping the dye solution into the photoreactor. 


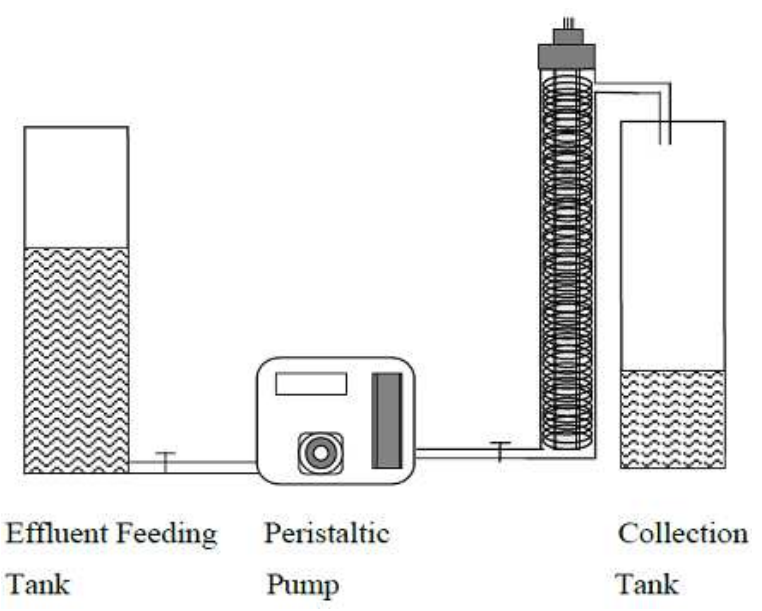

Fig. 1. The photooxidation system

The feeding tank had a fixed bottom made of Plexiglas ${ }^{\mathrm{TM}}$ and a small outlet port (4 mm diameter) near the bottom to connect the feeding tank to the feeding pump. An identical container was used at the other end of the system to collect the effluent after treatment.

A peristaltic pump (Digi-Staltic, Masterflex Model No: 7523-60, Head Model 77200-50. Barnant Company, Division of Cole Parmer Instrument Co., Barrington, IL, USA.) was used to control the flow rate of the dye solution into the reactor. The pump was connected to the feeding tank and the photoreactor by means of Masterflex precision tubing (06409-14 TYGON, Cole-Parmer Canada Inc., 210-5101, Montreal, Canada.).

\subsection{Chemicals}

The chemicals used in this study were reactive red 120 dye, hydrogen peroxide, sodium hydroxide and hydrochloric acid. The reactive red 120 (HE3B) dye used in this study was obtained from Sigma Aldrich (R0378-50G, CAS\# 61951-82-4, Sigma-Aldrich Inc., St-Louis, MO, USA), 30\% Hydrogen peroxide was obtained from Fisher Scientific (Ca \#H-325-500, Fisher scientific, Montreal, Quebec, Canada). The sodium hydroxide $(\mathrm{NaOH})$ and hydrochloric acid $(\mathrm{HCl})$ were used to adjust the $\mathrm{pH}$ to 10.5 (within the $\mathrm{pH}$ range of textile effluents of 10-11) and/or to 3 . The properties of the reactive red 120 dye are as shown in Table 1.

\subsection{Dye Preparation}

Reactive red 120 dye concentrations ranging from 50 to $500 \mathrm{mg} / \mathrm{L}$ were prepared by dissolving the desired amount of dye in $12 \mathrm{~L}$ of water. A digital balance (Model No: PI 314, Denver Instruments, Bohemia, New York, USA) was used to weigh the required amount of dye powder.

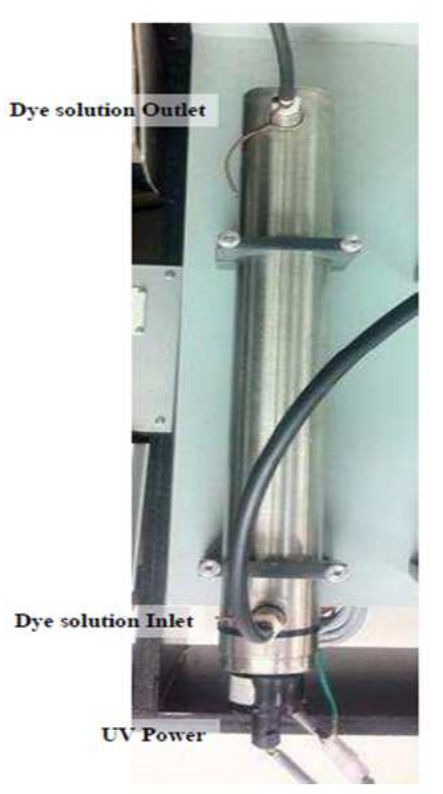

Fig. 2. Photo reactor

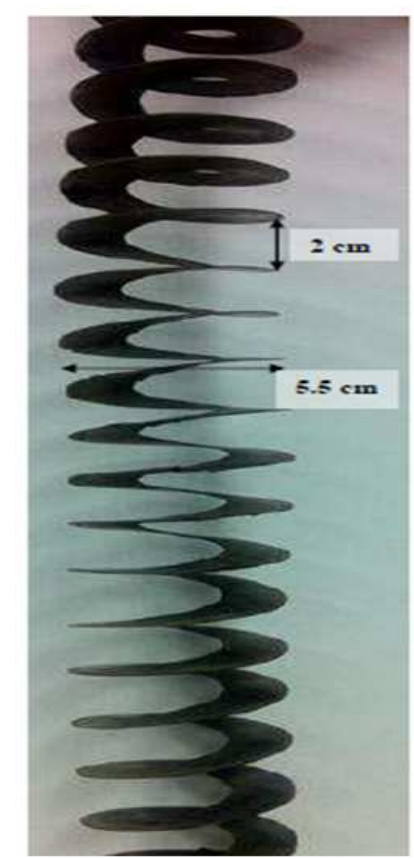

Fig. 3. Stainless steel coil

The dye was then stirred in the water using a magnetic stirrer (Model No: 120S, Fisher Scientific, Ottawa, Ontario, Canada). The resulting solution had a neutral $\mathrm{pH}$ of 7. The $\mathrm{pH}$ of the solution was adjusted to 10.5 using $\mathrm{NaOH}$. $\mathrm{HCl}$ was used to adjust the $\mathrm{pH}$ of another batch of 
the dye solution to 3 . The $\mathrm{pH}$ was read using a $\mathrm{pH}$ meter (UB-10 Denver Instruments, Bohemia, New York, USA).

\subsection{Experimental Procedure}

The degradation efficiency of reactive red 120 dye under exposure to $\mathrm{UV}$ alone and $\mathrm{UV} / \mathrm{H}_{2} \mathrm{O}_{2}$ was investigated in this study. Ten reactive red 120 dye concentrations $(50$, $100,150,200,250,300,350,400,450,500 \mathrm{mg} / \mathrm{L})$ were tested under 12 different residence times $(5.25,10,15,20$, 25.45, 30, 46.66, 49.41, 56 and $60 \mathrm{~min}$ ) using UV and $\mathrm{UV} / \mathrm{H}_{2} \mathrm{O}_{2}$. Two $\mathrm{H}_{2} \mathrm{O}_{2}$.concentration (10 and $20 \mathrm{ml} / \mathrm{L} \mathrm{H}_{2} \mathrm{O}_{2}$ ) were investigated. The flow rate of the peristaltic pump was calculated by dividing the reactor volume by the retention time. The flow rates and the corresponding retention times used in this study are listed in Table 2.

The first set of experiments was carried out using UV alone. The alkaline $(\mathrm{pH}=10.5)$ least concentrated dye solution $(50 \mathrm{mg} / \mathrm{L})$ was placed inside the feeding tank and the optical density (OD) was determined. The solution was fed into the photoreactor at the shortest retention time determination. The same procedure was carried out for all dye concentrations and retention times.

The second set of experiments was carried out using UV with $10 \mathrm{ml} / \mathrm{L} \mathrm{H}_{2} \mathrm{O}_{2}$. The alkaline $(\mathrm{pH}=10.5)$ least concentrated dye solution $(50 \mathrm{mg} / \mathrm{L})$ was mixed with 10 $\mathrm{ml} / \mathrm{L} \mathrm{H}_{2} \mathrm{O}_{2}$ and placed inside the feeding tank. The optical density (OD) was determined and the solution was fed into the photoreactor at the shortest retention time of $5.2 \mathrm{~min}$. Samples were collected from the effluent after reaching steady state and the OD was determined. The same procedure was carried out with all dye concentrations and flow rates.

The third set of experiments was carried out using $\mathrm{UV}$ with $20 \mathrm{ml} / \mathrm{L} \mathrm{H}_{2} \mathrm{O}_{2}$. The alkaline $(\mathrm{pH}=10.5)$ least concentrated dye solution $(50 \mathrm{mg} / \mathrm{L})$ was mixed with 20 $\mathrm{ml} / \mathrm{L} \mathrm{H}_{2} \mathrm{O}_{2}$ and placed inside the feeding tank. The optical density (OD) and chemical oxygen demand (COD) of the dye solution were determined. The dye solution was then fed into the photoreactor at the shortest retention time of $5.2 \mathrm{~min}$. Samples were collected from the effluent after reaching steady state and the OD and COD were determined. The same procedure was carried out with all dye concentrations and flow rates.

The fourth set of experiments was carried out using the best treatment $\left(\mathrm{UV} / 20 \mathrm{ml} / \mathrm{L} \mathrm{H}_{2} \mathrm{O}_{2}\right)$ with the acidic $(\mathrm{pH}=3)$ dye solutions. The least concentrated acidic $(\mathrm{pH}=3)$ dye solution $(50 \mathrm{mg} / \mathrm{L})$ was mixed with $20 \mathrm{ml} / \mathrm{L}$ $\mathrm{H}_{2} \mathrm{O}_{2}$ and placed inside the feeding tank. The optical density (OD) and the chemical oxygen demand (COD) of the dye solution were determined. The dye solution was then fed into the photoreactor at the shortest retention time of $5.2 \mathrm{~min}$. Samples were collected from the effluent after reaching steady state and the OD and COD
Table 1. Properties of reactive dye 120 (Red HE3B) (Vinitnantharat et al., 2003).

\begin{tabular}{lc}
\hline Properties & Value \\
\hline Chemical formula & $\mathrm{C}_{44} \mathrm{H}_{24} \mathrm{Cl}_{12} \mathrm{~N}_{14} \mathrm{Na}_{6} \mathrm{O}_{20} \mathrm{~S}_{6}$ \\
Molecular weight & 1338.09 \\
Molar Mass & 1470 \\
Charge & Negative \\
Functional group & Diazo \\
Colour & Bright red \\
$\lambda_{\text {max }}(\mathrm{nm})$ & 511 \\
Structure &
\end{tabular}

Table 2. Flow rate and the corresponding retention time.

\begin{tabular}{lc}
\hline $\begin{array}{c}\text { Flow rate } \\
(\mathrm{ml} / \mathrm{min})\end{array}$ & $\begin{array}{c}\text { Retention Time } \\
(\mathrm{min})\end{array}$ \\
\hline 160 & 05.25 \\
84 & 10.00 \\
56 & 15.00 \\
42 & 20.00 \\
33 & 25.45 \\
28 & 30.00 \\
24 & 35.00 \\
21 & 40.00 \\
18 & 46.66 \\
17 & 49.41 \\
15 & 56.00 \\
14 & 60.00 \\
\hline
\end{tabular}

were determined. The same procedure was carried out with all dye solutions and flow rates.

\subsection{Experimental Analyses}

The chemical oxygen demand (COD) was determined according to the procedure described by APHA (1990). The optical density (OD) of the samples was determined using a spectrophotometer (DR/2500 Illuminator Model, HACH Company, Love land, Colorado, U.S.A) at $535 \mathrm{~nm}$. A dye standard curve was prepared by measuring the OD of samples taken from the ten dye concentrations $(50,100,150,200,250,300$, $350,400,450$ and $500 \mathrm{mg} / \mathrm{L}$ ) at $535 \mathrm{~nm}$ and plotting the OD values against the dye concentrations. The standard curve (Figure 4) was used to determine the dye concentration in the treated solutions. 


\section{RESULTS}

\subsection{UV Treatment}

The dye degradation efficiencies of the alkaline $(\mathrm{pH}$ $=10.5$ ) dye solutions as a result of exposure to UV alone are shown in Figure 5. When the alkaline $(\mathrm{pH}=10.5)$ least concentrated $(50 \mathrm{mg} / \mathrm{L})$ dye solution was exposed to UV alone, a maximum degradation efficiency of $27.1 \%$ was achieved with the longest retention time of 60 min and only a degradation efficiency of $1.14 \%$ was achieved with the shortest retention time of $5.2 \mathrm{~min}$. When the alkaline $(\mathrm{pH}=10.5)$ most concentrated $(500$ $\mathrm{mg} / \mathrm{L}$ ) dye solution was exposed to UV alone, a degradation efficiency of $0.33 \%$ was achieved with the longest retention time of $60 \mathrm{~min}$ and no degradation was observed with retention times lower than $60 \mathrm{~min}$.

\section{2. $\mathrm{UV} / 10 \mathrm{~mL} / \mathrm{L} \mathrm{H}_{2} \mathrm{O}_{2}$ Treatment}

The degradation efficiencies of the alkaline $(\mathrm{pH}=3)$ dye solutions as a result of exposure to UV/10 ml/L $\mathrm{H}_{2} \mathrm{O}_{2}$ are shown in Figure 6. For the alkaline $(\mathrm{pH}=10.5)$ least concentrated $(50 \mathrm{mg} / \mathrm{L})$ dye solution, a maximum degradation efficiency of $93.62 \%$ was obtained when the dye solution was exposed to $\mathrm{UV} / 10 \mathrm{ml} \mathrm{H}_{2} \mathrm{O}_{2}$ for the shortest retention time of $5.2 \mathrm{~min}$ and a maximum degradation of $99.83 \%$ was obtained when the dye solution was exposed to UV/ $10 \mathrm{ml} / \mathrm{L} \mathrm{H}_{2} \mathrm{O}_{2}$ for $25.4 \mathrm{~min}$. For the alkaline $(\mathrm{pH}=10.5)$ most concentrated $(500 \mathrm{mg} / \mathrm{L})$ dye solution, a maximum degradation efficiency of $20.46 \%$ was observed with the shortest retention time of $5.2 \mathrm{~min}$ and a maximum degradation efficiency of $99.70 \%$ was obtained with the longest retention time of $60 \mathrm{~min}$.

\section{3. $\mathrm{UV} / 20 \mathrm{~mL} / \mathrm{L} \mathrm{H}_{2} \mathrm{O}_{2}$ Treatment}

The dye degradation efficiencies of the alkaline $(\mathrm{pH}$ $=10.5$ ) dye solutions obtained as a result of exposure to $\mathrm{UV} / 20 \mathrm{ml} / \mathrm{L} \mathrm{H}_{2} \mathrm{O}_{2}$ are shown in Figure 7 . When the alkaline $(\mathrm{pH}=10.5)$ least concentrated $(50 \mathrm{mg} / \mathrm{L})$ dye solution was exposed to $\mathrm{UV} / 20 \mathrm{ml} \mathrm{H}_{2} \mathrm{O}_{2}$, a maximum degradation efficiency of $94.2 \%$ was obtained with the shortest retention time of $5.2 \mathrm{~min}$ while a maximum degradation efficiency of $99.96 \%$ was obtained when the dye solution was exposed to UV/ $20 \mathrm{ml} / \mathrm{L} \mathrm{H}_{2} \mathrm{O}_{2}$ for $20 \mathrm{~min}$. For the alkaline $(\mathrm{pH}=10.5)$ most concentrated $(500 \mathrm{mg} / \mathrm{L})$ dye solution, a maximum degradation efficiency of $23.33 \%$ was observed with the shortest retention time of $5.2 \mathrm{~min}$ and a maximum $99.95 \%$ degradation efficiency was obtained with the longest retention time of $60 \mathrm{~min}$.

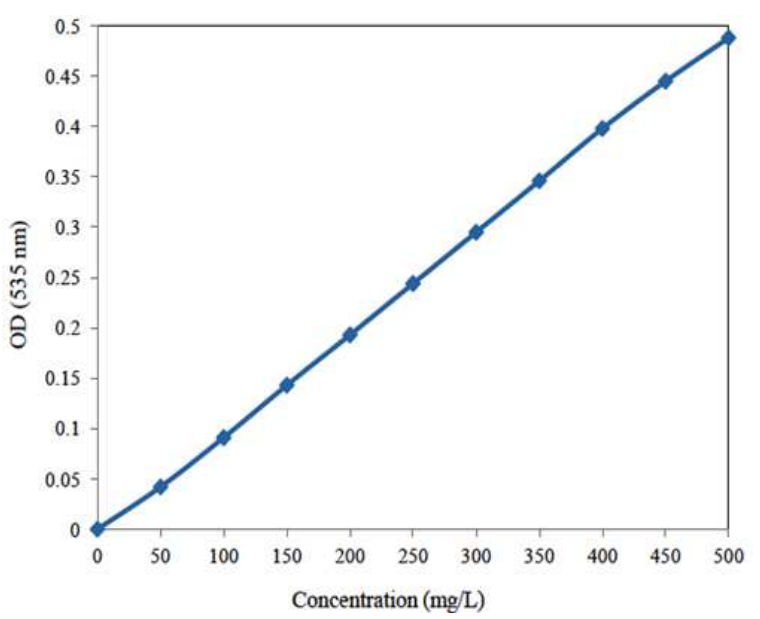

Fig. 4. Standard curve for dye concentration

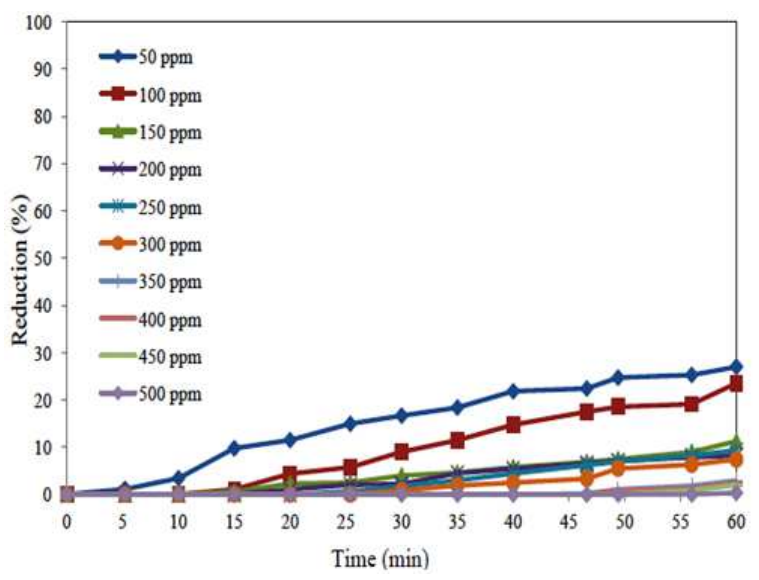

Fig. 5. Degradation efficiency of reactive red 120 when treated with UV

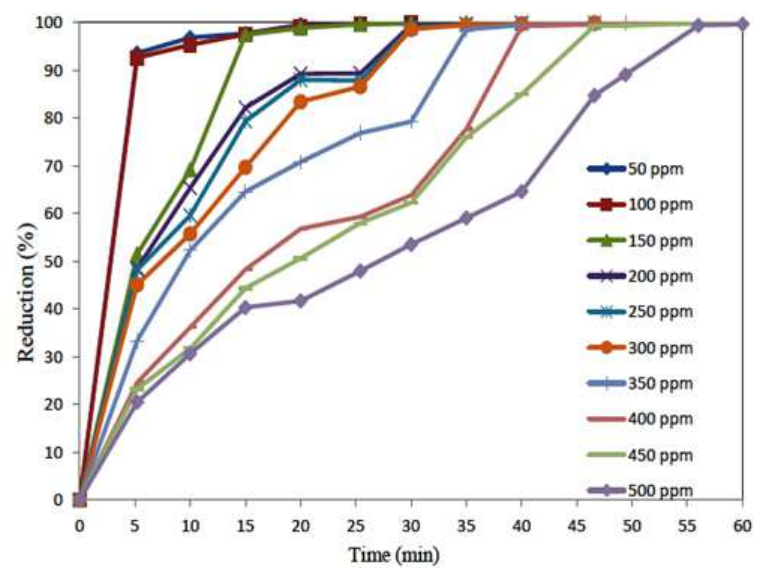

Fig. 6. Degradation efficiency of reactive red 120 when treated with $\mathrm{UV} / 10 \mathrm{~mL} \mathrm{H} \mathrm{O}_{2}$ 


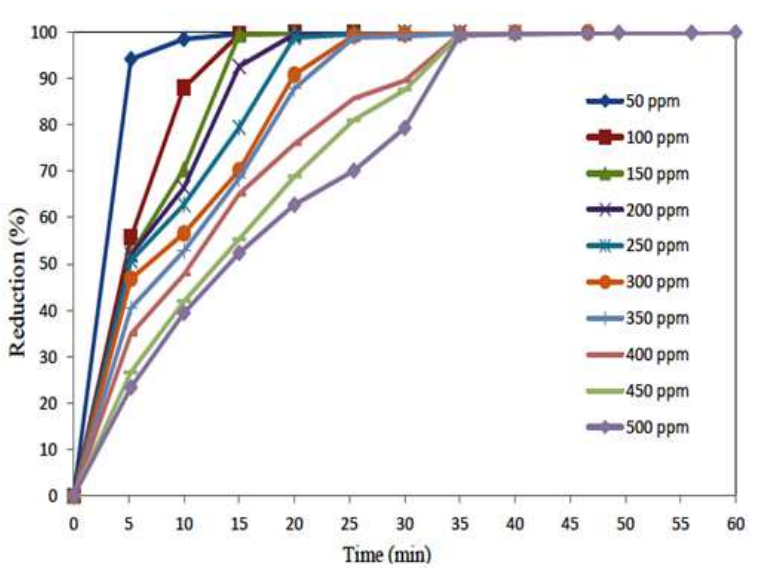

Fig. 7. Degradation efficiency of reactive red 120 when treated with $\mathrm{UV} / 20 \mathrm{~mL} \mathrm{H}_{2} \mathrm{O}_{2}$

\subsection{Chemical Oxygen Demand}

The initial results obtained from UV/20 $\mathrm{ml} / \mathrm{L} \mathrm{H}_{2} \mathrm{O}_{2}$ provided a better degradation than $\mathrm{UV}$ alone and $\mathrm{UV} / 10$ $\mathrm{ml} / \mathrm{L} \mathrm{H}_{2} \mathrm{O}_{2}$. Therefore, the amount of chemicals in the influent (before treatment) and effluent (after treatment) was determined by performing COD on the samples. The results obtained from the COD analysis are as shown in Figure 8. The highest COD concentration of 704-1184 $\mathrm{mg} / \mathrm{L}$ (depending on the dye concentration) was observed at 5 minutes from the start of the treatment. The COD then decreased reaching $256-416 \mathrm{mg} / \mathrm{L}$ by the end of the experiments, depending on the dye concentration.

\section{DISCUSSION}

\subsection{UV Treatment}

The decomposition of textile effluent when exposed to UV could be explained by the following reactions (SET, 2012; EPA US, 2012).

$$
\begin{array}{ll}
\mathrm{O}_{2} & \stackrel{h v(\text { UV })}{\longrightarrow} \mathrm{O}^{\circ}+\mathrm{O}^{\circ} \\
\mathrm{O}^{\circ}+\mathrm{O}_{2} & \stackrel{h v(\mathrm{UV})}{\longrightarrow} \mathrm{O}_{3} \\
\mathrm{O}_{3}+\mathrm{H}_{2} \mathrm{O} & \stackrel{h v(\mathrm{UV})}{\longrightarrow} \mathrm{O}_{2}+\mathrm{H}_{2} \mathrm{O}_{2} \\
2 \mathrm{O}_{3}+\mathrm{H}_{2} \mathrm{O}_{2} & \stackrel{h v(\mathrm{UV})}{\longrightarrow} 2 \mathrm{OH}^{\circ}+3 \mathrm{O}_{2} \\
\mathrm{OH}^{\circ}+\text { Organics } & \stackrel{\text { Erd Product }}{\longrightarrow}
\end{array}
$$

Equation 1 shows the production of atomic oxygen radicals as a result of exposure to UV. The oxygen radical $\left(\mathrm{O}^{\circ}\right)$ in turn reacts with other oxygen molecules resulting in the production of ozone $\left(\mathrm{O}_{3}\right)$ as shown in Equation 2 . Equation 3 shows the reaction between ozone and water which results in the production of hydrogen peroxide $\left(\mathrm{H}_{2} \mathrm{O}_{2}\right)$. Ozone then interacts with hydrogen peroxide to form hydroxyl radicals $\left(\mathrm{OH}^{\circ}\right)$ as shown in Equation 4.

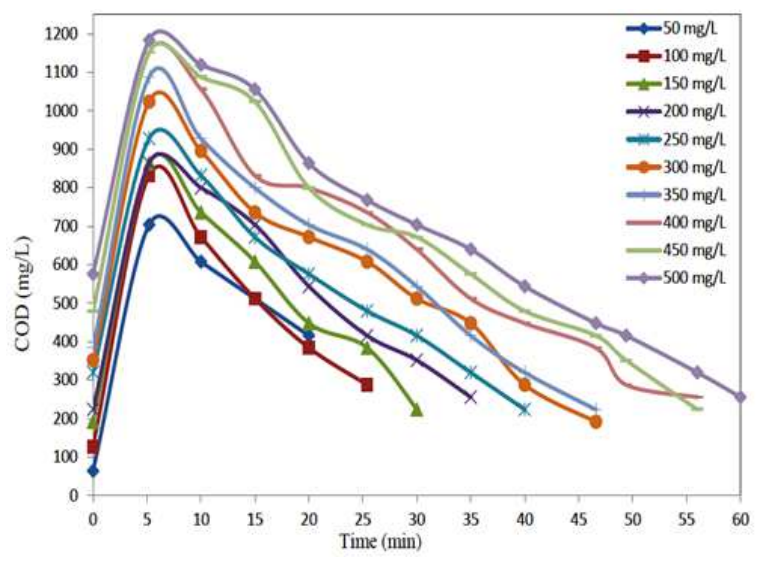

Fig. 8. Chemical oxygen demand of the alkaline solution after treatment with $\mathrm{UV} / 20 \mathrm{~mL} \mathrm{H} \mathrm{O}_{2}$.

Finally, the produced hydroxyl radicals interact with the dye molecules causing the destruction of the dye.

The maximum degradations achieved when the alkaline $(\mathrm{pH}=10.5)$ least concentrated $(50 \mathrm{mg} / \mathrm{L})$ and most concentrated $(500 \mathrm{mg} / \mathrm{L})$ dye solutions were exposed to UV alone for $60 \mathrm{~min}$ were $27.01 \%$ and $0.33 \%$, respectively. The results showed that as the dye concentration was increased the dye removal efficiency decreased. No reduction in the dye concentration was witnessed when the alkaline $(\mathrm{pH}=10.5)$ most concentrated $(500 \mathrm{mg} / \mathrm{L})$ dye solution was exposed to the UV alone for less than 56 minutes. The low removal efficiency observed in this study was due to the low quantity of hydroxyl radicals produced in the photoreactor and/or the very short life span of ozone and hydrogen peroxide as reported by Kesselman et al. (1996).

Several researchers indicated that the use of UV alone as photooxidant was not very effective in destroying textile dyes. Georgiou et al. (2002) observed no colour reduction when remazol black B dye solutions were treated with UV alone. Ince and Gonenc (1997) treated an azo dye solution having a concentration of 40 $\mathrm{mg} / \mathrm{L}$ with UV alone in a photoreactor and observed no significant decomposition of the dye. Ozkan et al. (2004) treated azo dyes with UV alone and noted no colour reduction at pH 7 - 11. Galindo and Kalt (1999) stated that the disappearance of dye molecules when used with UV in the absence of other oxidants was negligible. Verma and Ghaly (2008) stated that degradation of textile dyes with UV alone was not effective unless it was accompanied with other photocatalysts. However, in this study, upto $27 \%$ removal of the dye was achieved under alkaline condition when the $60 \mathrm{~min}$ retention time was used. Therefore, it would be possible to achieve higher removal efficiencies with UV alone using longer retention times. 


\section{2. $\mathrm{UV} / \mathrm{H}_{2} \mathrm{O}_{2}$ Treatment}

$\mathrm{UV}$ and $\mathrm{H}_{2} \mathrm{O}_{2}$ with different concentrations were used to treat the reactive red 120 dye solution (with different concentrations) under alkaline condition in this study. El-Dein et al. (2003) and Daneshvar et al. (2005) proposed the following mechanism for the decolourization of organics with the $\mathrm{H}_{2} \mathrm{O}_{2} / \mathrm{UV}$ process. The mechanism includes three steps: initiation, hydroxyl radical propagation and termination.

Initiation

$\mathrm{H}_{2} \mathrm{O}_{2}$

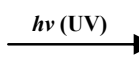

$2 \mathrm{OH}^{\circ}$

Hydroxyl radical propagation

$$
\begin{aligned}
& \mathrm{H}_{2} \mathrm{O}_{2}+\mathrm{OH}^{\circ} \\
& \mathrm{H}_{2} \mathrm{O}_{2}+\mathrm{HO}_{2}^{\circ} \\
& \mathrm{H}_{2} \mathrm{O}_{2}+\mathrm{OH}^{\circ} \\
& \mathrm{H}_{2} \mathrm{O}_{2}+\mathrm{O}_{2}^{\circ}
\end{aligned}
$$

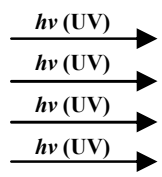

$$
\begin{aligned}
& \mathrm{HO}_{2}{ }^{\circ}+\mathrm{H}_{2} \mathrm{O} \\
& \mathrm{OH}^{\circ}+\mathrm{O}_{2}+\mathrm{H}_{2} \mathrm{O}(8) \\
& \mathrm{O}_{2}{ }^{-}+\mathrm{H}^{+}+\mathrm{H}_{2} \mathrm{O}(9) \\
& \mathrm{OH}^{\circ}+\mathrm{OH}^{-}+\mathrm{O}_{2}(10)
\end{aligned}
$$

Hydroxyl radical termination

$$
\begin{array}{lll}
\mathrm{OH}^{-}+\mathrm{H}^{+} & \stackrel{\boldsymbol{h v}(\mathbf{U v})}{\longrightarrow} \mathrm{H}_{2} \mathrm{O} \\
\mathrm{Dye}+\mathrm{OH}^{\circ} & \stackrel{\boldsymbol{h}(\mathbf{U v})}{\longrightarrow} & \text { End Product } \\
\text { Dye-OH }+\mathrm{OH}^{\circ} & \stackrel{\boldsymbol{h v}(\mathbf{U V})}{\longrightarrow} \text { End Product }
\end{array}
$$

Equation 6 shows the initiation reaction between UV and $\mathrm{H}_{2} \mathrm{O}_{2}$ leading to the production of hydroxyl radicals $\left(\mathrm{OH}^{\circ}\right)$. Equations 7, 8, 9 and 10 show the propagation of the reaction involving the production of hydroxyl radicals which helps in the reduction of dye molecules. Equations 11, 12 and 13 show the termination of the reactions which result in the formation of end Product.

When the alkaline $(\mathrm{pH}=10.5)$ reactive red 120 dye solutions of different concentrations $(50-500 \mathrm{mg} / \mathrm{L})$ were treated with $\mathrm{UV} / 10 \mathrm{ml} / \mathrm{L} \quad \mathrm{H}_{2} \mathrm{O}_{2}$, near complete degradation $(99.70$ - 99.96\%) was observed for all the concentrations. However, the time required for complete degradation depended on the initial dye concentration. The results showed that $99.83 \%$ degradation efficiency was achieved for the alkaline $(\mathrm{pH}=10.5)$ least concentrated $(50 \mathrm{mg} / \mathrm{L})$ dye solution after $25.4 \mathrm{~min}$ when the solution was exposed to $\mathrm{UV} / 10 \mathrm{ml} / \mathrm{L} \mathrm{H}_{2} \mathrm{O}_{2}$. However, when $\mathrm{UV} / 20 \mathrm{ml} / \mathrm{L} \mathrm{H}_{2} \mathrm{O}_{2}$ was used with the same dye concentration, $99.96 \%$ degradation efficiency was achieved after $20 \mathrm{~min}$. When the alkaline $(\mathrm{pH}=10.5)$ most concentrated dye solution $(500 \mathrm{mg} / \mathrm{L})$ was treated with $\mathrm{UV} / 10 \mathrm{ml} / \mathrm{L} \mathrm{H}_{2} \mathrm{O}_{2}$, a degradation efficiency of
99.70\% was obtained after $60 \mathrm{~min}$ but when $\mathrm{UV} / 20 \mathrm{ml} / \mathrm{L}$ $\mathrm{H}_{2} \mathrm{O}_{2}$ was used with the same dye concentration, $99.95 \%$ degradation efficiency was obtained after $60 \mathrm{~min}$.

Kdasi et al. (2004) stated that treatment of textile dyes with $\mathrm{UV} / \mathrm{H}_{2} \mathrm{O}_{2}$ was more effective than the treatment with $\mathrm{H}_{2} \mathrm{O}_{2}$ alone. Kurbus et al. (2003) noted that the decolourisation time required for $\mathrm{H}_{2} \mathrm{O}_{2} / \mathrm{UV}$ process was less than the time required for $\mathrm{H}_{2} \mathrm{O}_{2} / \mathrm{O}_{3}$. Shu and Chang (2005) compared the decolourization effects of six different azo dyes and found that more than $95 \%$ degradation efficiency was achieved when the dye solution was treated with $\mathrm{UV} / \mathrm{H}_{2} \mathrm{O}_{2}$ in less than $11.5 \mathrm{~min}$, which was higher than the degradation rate achieved with $\mathrm{UV} / \mathrm{O}_{3}$ for the same time period. Galindo et al. (1999) noted that the actions of UV alone or $\mathrm{H}_{2} \mathrm{O}_{2}$ alone on the azo dyes were found to be ineffective (as more than $99 \%$ of dye remained in the system after treatment for $120 \mathrm{~min}$ ) but when the same sample was treated with a combination of $\mathrm{UV} / \mathrm{H}_{2} \mathrm{O}_{2}$, a dramatic increase in the degradation efficiency of the dye was observed. Verma and Ghaly (2008) reported a $99.9 \%$ degradation of 300 $\mathrm{mg} / \mathrm{L}$ ramazol dye when treated with $\mathrm{UV} / \mathrm{H}_{2} \mathrm{O}_{2}$ at a retention time of $42 \mathrm{~min}$, which was a much greater degradation than those obtained with just UV or $\mathrm{H}_{2} \mathrm{O}_{2}$. Georgiou et al. (2002) reported that more than 50\% degradation of $100 \mathrm{mg} / \mathrm{L}$ reactive dyes was obtained within $20 \mathrm{~min}$ under $\mathrm{UV} / \mathrm{H}_{2} \mathrm{O}_{2}$. Perkowski and Kos (2003) reported that $99 \%$ degradation efficiency of the effluents from a dye house was achieved after 2 hours with $\mathrm{UV} / \mathrm{H}_{2} \mathrm{O}_{2}$. Yang et al. (1998) reported that a 95\% colour removal was achieved on some reactive, acid, direct and basic dyes when used with $\mathrm{UV} / \mathrm{H}_{2} \mathrm{O}_{2}$.

Crittenden et al. (1999) stated that when $\mathrm{H}_{2} \mathrm{O}_{2}$ is exposed to UV, it splits to two hydroxyl radicals which in turn react with the organics in the solution. Georgiou et al. (2002) noted that even a small amount of $\mathrm{H}_{2} \mathrm{O}_{2}(0.1$ $\mathrm{ml} / \mathrm{L}$ ) was found to completely destruct colour in less than an hour and if the peroxide amount was increased the destruction time was found to decrease. Modirshahla et al. (2007) reported that the improvement in decolourisation was not found to be significant above certain amount of $\mathrm{H}_{2} \mathrm{O}_{2}$ due to the recombination of hydroxyl radicals in the solution or the reaction between hydroxyl radicals and $\mathrm{H}_{2} \mathrm{O}_{2}$ creating hydroxyl radical scavenging capacity. White (2011) stated that excess amount of $\mathrm{H}_{2} \mathrm{O}_{2}$ added to the effluent for treatment might not cause an environmental hazard due to its capacity to degrade under sunlight as shown in Equation 14.

$2 \mathrm{H}_{2} \mathrm{O}_{2} \stackrel{\text { Sunlight }}{\longrightarrow} 2 \mathrm{H}_{2} \mathrm{O}+\mathrm{O}_{2}$ 


\subsection{Acidic Treatment}

The $50 \mathrm{mg} / \mathrm{L}$ and $500 \mathrm{mg} / \mathrm{L}$ dye concentrations were treated with the most efficient treatment (UV with 20 $\mathrm{ml} / \mathrm{L} \mathrm{H}_{2} \mathrm{O}_{2}$ ) at a $\mathrm{pH}$ of 3 in order to investigate the effect of $\mathrm{pH}$ on removal efficiency. The decolourisation of reactive red 120 dye was found to be faster when treated under acidic pH. A 99.97\% degradation efficiency was achieved after $15 \mathrm{~min}$ for the acidic $(\mathrm{pH}=3)$ least concentrated $(50 \mathrm{mg} / \mathrm{L})$ dye solution and $99.95 \%$ degradation efficiency was achieved after at $46.6 \mathrm{~min}$ for the acidic $(\mathrm{pH}=3)$ most concentrated $(500 \mathrm{mg} / \mathrm{L})$ dye solution compared to $99.96 \%$ after $20 \mathrm{~min}$ for the alkaline $(\mathrm{pH}=10.5)$ least concentrated $(50 \mathrm{mg} / \mathrm{L})$ dye solution and $99.95 \%$ after $60 \mathrm{~min}$ for the alkaline $(\mathrm{pH}=10.5)$ most concentrated $(500 \mathrm{mg} / \mathrm{L})$ dye solution as shown in Table 3. It was also observed that the $\mathrm{pH}$ of the dye solution was reduced further after the acidic treatment to 2.8 after 15 min exposure time for the least concentrated $(50 \mathrm{mg} / \mathrm{L})$ dye solution and to 2.5 after $46.6 \mathrm{~min}$ exposure time for the most concentrated $(500 \mathrm{mg} / \mathrm{L})$ dye solution.

Several researchers indicated that photooxidation is more efficient under acidic conditions than alkaline conditions. Galindo and Kalt (1999) reported that $\mathrm{H}_{2} \mathrm{O}_{2} / \mathrm{UV}$ oxidation was far more efficient when used under an acidic pH. They stated that when $\mathrm{H}_{2} \mathrm{O}_{2}$ was used with UV under an alkaline condition, it undergoes decomposition forming dioxygen and water which is believed to be the reason for the less initial concentration of $\mathrm{OH}^{\circ}$. Ganesan and Thanasekaran (2011) reported that the effect of $\mathrm{UV} / \mathrm{H}_{2} \mathrm{O}_{2}$ degradation decreases as the $\mathrm{pH}$ increases. They have also noted that the decolourisation efficiency increased as the concentration of $\mathrm{H}_{2} \mathrm{O}_{2}$ was increased due to the additional production of hydroxyl radicals. Kavitha and Palanisamy (2011) stated that the photocatalytic activity was maximum under acidic condition and was found to decrease when the $\mathrm{pH}$ range was increased above 6. Neamtu et al. (2003) examined the colour removal efficiency at different $\mathrm{pH}$ levels $(2$, $3,6.5$ and 9.7) and found the best colour removal efficiency $(99 \%)$ of the reactive red 120 was achieved at a $\mathrm{pH}$ of 2 within $15 \mathrm{~min}$. Azbar et al. (2004) reported that the best reductions of COD and colour were obtained when the treatment was performed under an acidic $\mathrm{pH}$ rather than an alkaline $\mathrm{pH}$.

In this study, the $\mathrm{pH}$ was adjusted to 10.5 which is the range of $\mathrm{pH}$ for textile effluent. After treatments, the $\mathrm{pH}$ decreased and the final $\mathrm{pH}$ of the treated effluent was however within the effluent $\mathrm{pH}$ discharge limits of 6-9.
Table 3. Maximum removal efficiency for various treatments.

\begin{tabular}{lcccc}
\hline Treatment & $\begin{array}{c}\text { Dye Concen- } \\
\text { tration } \\
(\mathrm{mg} / \mathrm{L})\end{array}$ & $\mathrm{pH}$ & $\begin{array}{c}\text { Time } \\
(\mathrm{min})\end{array}$ & $\begin{array}{c}\text { Maximum } \\
\text { Removal } \\
\text { Efficiency } \\
(\%)\end{array}$ \\
\hline $\mathrm{UV}$ & 50 & 10.5 & 60.0 & 27.01 \\
& 500 & 10.5 & 60.0 & 0.33 \\
\hline $\mathrm{UV} / 10 \mathrm{ml}$ & 50 & 10.5 & 25.4 & 99.83 \\
$\mathrm{H}_{2} \mathrm{O}_{2}$ & 500 & 10.5 & 60.0 & 99.70 \\
\hline $\mathrm{UV} / 20 \mathrm{ml}$ & 50 & 10.5 & 20.0 & 99.96 \\
$\mathrm{H}_{2} \mathrm{O}_{2}$ & 500 & 10.5 & 60.0 & 99.95 \\
\hline $\mathrm{UV} / 20 \mathrm{ml}$ & 50 & 3.0 & 15.0 & 99.97 \\
$\mathrm{H}_{2} \mathrm{O}_{2}$ & 500 & 3.0 & 60.0 & 99.95 \\
\hline
\end{tabular}

Although, treatment of textile dyes under acidic condition $(\mathrm{pH}=3)$ provided faster decolourisation $(16-25 \%)$ than those recorded under alkaline conditions, the decrease in decolourization time does not justify the disposal problems associated with lower $\mathrm{pH}$ and the cost of chemical addition to the influent to bring the $\mathrm{pH}$ to 3 before treatment and then to the effluent to bring the $\mathrm{pH}$ to the neutral value before final disposal.

\subsection{Chemical Oxygen Demand}

When the $\mathrm{H}_{2} \mathrm{O}_{2}$ was increased to $20 \mathrm{ml} / \mathrm{L}$ (UV/ 20 $\left.\mathrm{ml} / \mathrm{L} \mathrm{H}_{2} \mathrm{O}_{2}\right)$, the dye degradation was much better $(99.96 \%$ after $20 \mathrm{~min}$ for $50 \mathrm{mg} / \mathrm{L}$ dye concentration and $99.95 \%$ after $60 \mathrm{~min}$ for $500 \mathrm{mg} / \mathrm{L}$ dye concentration). Since the $\mathrm{UV} / 20 \mathrm{ml} / \mathrm{L} \mathrm{H}_{2} \mathrm{O}_{2}$ was the most efficient treatment for the dye at all concentrations, the Chemical Oxygen Demand (COD) analysis was performed on the samples obtained from the $\mathrm{UV} / 20 \mathrm{ml} / \mathrm{L} \mathrm{H}_{2} \mathrm{O}_{2}$ treatment to determine the amount of chemicals present in the solution after treatment. From the COD results it was evident that the longer the exposure time, the more the reduction in COD values $(416 \mathrm{mg} / \mathrm{L}$ for $50 \mathrm{mg} / \mathrm{L}$ dye concentration after 20 $\mathrm{min}$ and $256 \mathrm{mg} / \mathrm{L}$ for $500 \mathrm{mg} / \mathrm{L}$ dye concentration after $60 \mathrm{~min}$ ). Hence textile effluents could be exposed to UV/ $20 \mathrm{ml} / \mathrm{L} \mathrm{H}_{2} \mathrm{O}_{2}$ for more than $60 \mathrm{~min}$ to lower the COD to the disposal limit of $80 \mathrm{mg} / \mathrm{L}$ (CCME, 2012).

Soutsas et al. (2010) stated that, the COD reduction was a function of the dye concentration, the higher the dye concentration, the lower the reduction. They attained complete dye degradation when a dye concentration of $100 \mathrm{mg} / \mathrm{L}$ was exposed to $\mathrm{UV} / \mathrm{H}_{2} \mathrm{O}_{2}$, while only an $86 \%$ reduction was found when the solution was exposed to UV without $\mathrm{H}_{2} \mathrm{O}_{2}$. Azbar et al. (2004) reported COD reduction of $90 \%$ when polyester and acetate dyes were treated with $\mathrm{UV} / \mathrm{H}_{2} \mathrm{O}_{2}$ for a retention time of $90 \mathrm{~min}$, but they attained a higher COD and colour removal when they performed the experiments under an acidic 
condition (a pH of 3). Kurbus et al. (2003) reported a higher COD reduction with $\mathrm{H}_{2} \mathrm{O}_{2} / \mathrm{UV}$ compared to $\mathrm{H}_{2} \mathrm{O}_{2} / \mathrm{Fe}^{2+}$. Shu and Hsieh (2006) experimented with azo, acid and reactive dyes and noted $41.2 \%$ COD reduction after being exposed to UV alone for $180 \mathrm{~min}, 20 \% \mathrm{COD}$ reduction after being exposed to $\mathrm{H}_{2} \mathrm{O}_{2}$ alone for 72 hours and $99.5 \%$ COD reduction after being exposed to a combination of $\mathrm{UV}$ and $\mathrm{H}_{2} \mathrm{O}_{2}$ for 120 min. Bedoul et al. (2008) reported that the $\mathrm{COD}$ reduction rate was increased as the amount of $\mathrm{H}_{2} \mathrm{O}_{2}$ was increased from 1.8 $\mathrm{ml} / \mathrm{L}$ to $2.75 \mathrm{ml} / \mathrm{L}$.

The results obtained in this study showed that the increase in COD under acidic condition $(618 \mathrm{mg} / \mathrm{L}$ for $50 \mathrm{mg} / \mathrm{L}$ concentration and to $454 \mathrm{mg} / \mathrm{L}$ for $500 \mathrm{mg} / \mathrm{L}$ ) compared to that under alkaline condition $(416 \mathrm{mg} / \mathrm{L}$ for $50 \mathrm{mg} / \mathrm{L}$ concentration and $256 \mathrm{mg} / \mathrm{L}$ for $500 \mathrm{mg} / \mathrm{L}$ ) will require additional costly treatment.

\subsection{Effect of Temperature}

The current study was carried out at the ambient temperature $\left(25^{\circ} \mathrm{C}\right)$. Muruganandham and Swaminathan (2004) stated that the low pressure UV lamps were found to emit low energy and the rise in the temperature of the dye solution had no effect on the removal efficiency of reactive orange 4 . The authors stated that when textile dyes of various concentrations (78-390 mg/L) were exposed to low pressure UV lamps, the photons produced were not able to penetrate the organics and as a result the production of hydroxyl radicals $\left(\mathrm{OH}^{\circ}\right)$ are decreased (Equations 1-4). They also suggested the use of additional oxidants for effective removal efficiency.

Chaudhuri and Sur. (2000) reported to have no change in the degradation value of brilliant red 4BLI, orange 3RLI, scarlet PRI, Turquoise PBI and Yellow 4GI when treated with $\mathrm{UV} / \mathrm{H}_{2} \mathrm{O}_{2}$ at temperatures ranging from $29^{\circ} \mathrm{C}$ to $59^{\circ} \mathrm{C}$. Galindo and Kalt (1999) and Kdasi et al. (2004) reported no change in degradation values when the dyes acid orange 5, 6, 7, 20 and 52 were treated with $\mathrm{UV} / \mathrm{H}_{2} \mathrm{O}_{2}$ at temperatures ranging from $22^{\circ} \mathrm{C}$ to $45^{\circ} \mathrm{C}$. Mahmoud et al. (2007) observed decreases in decolourization efficiency of remazol brilliant blue dyes when the temperature was increased from 25 to $100^{\circ} \mathrm{C}$.

However, some reports in the literature indicated the influence of temperature on the dye degradation when UV is combined with other oxidants. Saien and Soleymani (2007) treated direct blue 71 and reported 7\% enhancement in dye degradation as the temperature was increased from $15{ }^{\circ} \mathrm{C}-45^{\circ} \mathrm{C}$. The authors suggested that the increase in temperature decreased the solubility of oxygen in water with the consequent reduction in the production of radicals $\left(\mathrm{O}^{\circ}, \mathrm{O}_{3}{ }^{\circ}\right.$ and $\left.\mathrm{H}_{2} \mathrm{O}_{2}\right)$ by $\mathrm{UV}$
(Equations 1, 2 and 3). They concluded a temperature higher than $45^{\circ} \mathrm{C}$ should not be used as it will result in low degradation efficiency.

\section{CONCLUSION}

Ten different concentrations of reactive red 120 dye were exposed to a low pressure UV lamp (380 nm intensity UV) alone and in a combination with $30 \%$ $\mathrm{H}_{2} \mathrm{O}_{2}$ (10 and $\left.20 \mathrm{ml} / \mathrm{L}\right)$ at twelve different retention times. The dye degradation efficiency obtained after 60 min exposure to UV alone was $27.01 \%$ for $50 \mathrm{mg} / \mathrm{L}$ dye concentration and $0.33 \%$ for $500 \mathrm{mg} / \mathrm{L}$ dye concentration. The degradation efficiency obtained after exposure to $\mathrm{UV} / 10 \mathrm{ml} / \mathrm{L} \mathrm{H}_{2} \mathrm{O}_{2}$ was $99.83 \%$ after 25.4 min for the $50 \mathrm{mg} / \mathrm{L}$ dye concentration and $99.70 \%$ after $60 \mathrm{~min}$ for the $500 \mathrm{mg} / \mathrm{L}$ dye concentration. Exposure to $\mathrm{UV} / 20 \mathrm{ml} / \mathrm{L} \mathrm{H}_{2} \mathrm{O}_{2}$ resulted in a degradation efficiency of $99.96 \%$ after $20 \mathrm{~min}$ for the $50 \mathrm{mg} / \mathrm{L}$ dye concentration and $99.95 \%$ after $60 \mathrm{~min}$ for the $500 \mathrm{mg} / \mathrm{L}$ dye concentration. Increasing the $\mathrm{H}_{2} \mathrm{O}_{2}$ from $10 \mathrm{ml} / \mathrm{L}$ to 20 $\mathrm{ml} / \mathrm{L} \quad\left(\mathrm{UV} / 20 \quad \mathrm{ml} / \mathrm{L} \quad \mathrm{H}_{2} \mathrm{O}_{2}\right)$ improved the oxidation efficiency and reduced the treatment time. The Chemical Oxygen Demand (COD) analysis performed on the effluent obtained from the treatment with UV/20 ml/L $\mathrm{H}_{2} \mathrm{O}_{2}$ showed a COD removal efficiency of $99.96 \%$ (from $704 \mathrm{mg} / \mathrm{L}$ to $416 \mathrm{mg} / \mathrm{L}$ ) after $20 \mathrm{~min}$ for the 50 $\mathrm{mg} / \mathrm{L}$ dye concentration and $99.95 \%$ (from $1184 \mathrm{mg} / \mathrm{L}$ to $256 \mathrm{mg} / \mathrm{L}$ ) after $60 \mathrm{~min}$ for the $500 \mathrm{mg} / \mathrm{L}$ dye concentrations. The final COD concentrations were higher than the COD discharge limit of $80 \mathrm{mg} / \mathrm{L}$. The COD discharge limit of $80 \mathrm{mg} / \mathrm{L}$ could be achieved with $\mathrm{UV} / 20 \mathrm{ml} / \mathrm{L} \mathrm{H}_{2} \mathrm{O}_{2}$ treatments by increasing the exposure time (longer than $60 \mathrm{~min}$ ). The $\mathrm{pH}$ of the treated effluent is within the accepted limit of 6-9. Treatment of the dye effluent under acidic condition was slightly faster but the time reduction does not justify the cost of chemicals addition to adjust the $\mathrm{pH}$ to 3 before treatment and then to 7 before discharge and the further treatment to remove the chemicals before disposal.

\section{ACKNOWLEDGEMENT}

This research project was supported by the Natural Science and Engineering Research Council (NSERC of Canada).

\section{REFERENCES}

Atif, S.M., 2002. Impact of Environmental Regulations on the Textile Sector of Pakistan, Geneva. 
Azbar, N., T. Yonar and K. Kestioqlu, 2004. Comparison of various advanced oxidation processes and chemical treatment methods for COD and color removal from a polyester and acetate fiber dyeing effluent. Chemosphere, 55: 35-43. DOI: 10.1016/j.chemosphere.2003.10.046

Babu, R., A. Parande, S. Raghu and T. Kumar, 2007. Textile technology-cotton textile processing: Waste generation and effluent treatment. J. Cotton Sci., 11: 141-153.

Bedoul, A., K. Sindl and N. Bensalah, 2008. treatment of refractory organics contained in actual agro-industrial wastewaters by $\mathrm{UV} / \mathrm{H}_{2} \mathrm{O}_{2}$. Clean, 36: 373-379.

CCME, 2012. Canadian Environmental Quality Guidelines and Summary Table.

Chaudhuri, S. and B. Sur, 2000. Oxidative decolourization of reactive dye solution using fly ash as catalyst. Environ. Eng., 16: 583-594.

Crittenden, J., S. Hu, D. Hand and S. Green, 1999. A kinetic model for $\mathrm{H}_{2} \mathrm{O}_{2} / \mathrm{UV}$ process in a completely mixed batch reactor. Water Res., 33: 2315-2328. DOI: 10.1016/S0043-1354(98)00448-5

Daneshvar, N., A. Aleboyeh and A. Khataee, 2005. The evaluation of electrical energy per order $\left(\mathrm{E}_{\mathrm{E} 0}\right)$ for photooxidative decolorization of four textile dye solutions by the kinetic model. Chemosphere, 59: 761-767. DOI: 10.1016/j.chemosphere.2004.11.012

Das, S., 2000. Textile effluent treatment - A Solution to the environmental pollution.

Dyes and Pigments, 2010. Textile Dyes.

El-Dein, A., J. Libra and U. Wiesmann, 2003. Mechanism and kinetic model for the decolorization of the azo dye Reactive Black 5 by hydrogen peroxide and UV radiation. Chemosphere, 52: 1069-1077. PMID: 12781240

EPA, 2003. Wastewater Technology Fact Sheet Screening and Grit Removal. Environmental Protection Agency,

EPA US, 2012. Environmental Protection Agency United States.

Eswaramoorthi, S., K. Dhanapal and D. Chauhan, 2008. Advanced in Textile Waste Water Treatment: The Case for UV-Ozonation and Membrane Bioreactor for Common Effluent Treatment Plants in Tirupur, Tamil $\mathrm{Nadu}$, India. Environment with People's Involvement and Co-ordination in India. Coimbatore, India.

Fashion Products, 2012. Fashion Apparel Industry Overview.

Galindo, C. and A. Kalt, 1999. UV-H2O2 oxidation of monoazo dyes in aqueous media: A kinetic study. Dyes Pigments, 40: 27-35. DOI: 10.1016/S0143-7208(98)00027-8
Galindo, C., P. Jacques and A. Kalt, 1999. Photodegradation of the aminoazobenzene acid orange 52 by three advanced oxidation processes: $\mathrm{UV} / \mathrm{H} 2 \mathrm{O} 2, \mathrm{UV} / \mathrm{TiO} 2$ and VIS/TiO2: Comparative mechanistic and kinetic investigations. J. Photochem. Photobiol., 130: 35-47. DOI: 10.1016/S1010-6030(99)00199-9

Ganesan, R. and K. Thanasekaran, 2011. Decolourisation of textile dyeing wastewater by modified solar photo-fenton oxidation. Int. J. Environ. Sci., 1: 1168-1176.

Georgiou, D., P. Melidis, A. Aivasidis and K. Gimouhopouls, 2002. Degradation of azo-reactive dyes by ultraviolet radiation in the presence of hydrogen peroxide, Dyes Pigments, 52: 69-78. DOI: 10.1016/S0143-7208(01)00078-X

Gereffi, G., 2002. Outsourcing and changing patterns of international competition in the apparel commodity chain. Uniersity of Colorado Boulder.

Ghoreishi, S. and R. Haghighi, 2003. Chemical catalytic reaction and biological oxidation for treatment of non-biodegradable textile effluent. Chemical. Eng. J., 95: 163-169. DOI: 10.1016/S1385-8947(03)00100-1

Gogate, P. and A. Pandit, 2004. A review of imperative technologies for wastewater treatment I: Oxidation technologies at ambient conditions. Adv. Environ., 8: 501-551. DOI: 10.1016/S1093-0191(03)00032-7

Ince, N. and D. Gonenc, 1997. Treatability of a Textile Azo Dye by $\mathrm{UV} / \mathrm{H}_{2} \mathrm{O}_{2}$. Environ. Tech., 18: 179-185. DOI: 10.1080/09593330.1997.9618484

Jain, R., M. Bhargava and N. Sharma, 2003. Electrochemical studies on a pharmaceutical azo dye: Tartrazine. Ind. Eng. Chem. Res., 42: 243-247. DOI: $10.1021 / \mathrm{ie} 020228 \mathrm{q}$

Kant, R., 2012. Textile dyeing industry an environmental hazard. Univ. Inst. Fashion Tech, 4: 22-26. DOI: 10.4236/ns.2012.41004

Kavitha, S. and P. Palanisamy, 2011. Photocatalytic and sonophotocatalytic degradation of reactive red 120 using dye sensitized $\mathrm{TiO}_{2}$ under visible light. Int. J. Civil Environ. Eng., 3: 73-89.

Kdasi, A., A. Idris, K. Saed and C. Guan, 2004. Treatment of textile wastewater by advanced oxidation processes - a review. Global Nest. Int. J., 6: 222-230.

Keane, J. and D. Velde, 2008. The role of textile and clothing industried in growth and development strategies. Investment and Growth Programme. Overseas Development Institute. 
Kesselman, J., O. Weres, N. Lewis and M. Hoffmann, 1996. Electrochemical production of hydroxyl radical at polycrystalline nb-doped $\mathrm{TiO}_{2}$ electrodes and estimation of the partitioning between hydroxyl radical and direct hole oxidation pathways. J. Phys. Chem. B,101: 2637-2643. DOI: 10.1021/jp962669r

Kurbus, T., A. Marechal and D. Voncina, 2003. Comparison of $\mathrm{H}_{2} \mathrm{O}_{2} / \mathrm{UV}, \mathrm{H}_{2} \mathrm{O}_{2} / \mathrm{O}_{3}$ and $\mathrm{H}_{2} \mathrm{O}_{2} / \mathrm{Fe}^{2+}$ processes for the decolorisation of vinylsulphone reactive dyes. Dyes Pigments, 58: 245-252. DOI:10.1016/S0143-7208(03)00085-8

Lafond, R., 2008. Moving Bed Biofilm Reactor (MBBR) A Compact Technology for Upgrading Canadian Municipal Aerated Lagoons. VP Business Development and Marketing.

Laxman, M.S., 2009. Pollution and its control in textile industry. San Blue Enterprises Pvt. Ltd.

Mahmoud, A., M. Brooks and A. Ghaly, 2007. decolorization of remazol brilliant blue dye effluent by advanced photo oxidation process (H2O2/UV system). Am. J. Applied Sci., 4: 1054-1062. DOI: 10.3844/ajassp.2007.1054.1062

Mathur, N., P. Bhatnagar, P. Nagar and M. Bijarnia, 2005. Mutagenicity Assessment of Effluents from Textile/Dye Industries of Sanganer, Jaipur (India): A Case Study. Ecotoxicol. Enviro. Safety, 61: 105-113. PMID: 15814316

Modirshahla, N., M. Behnajady and F. Ghanbary, 2007. Decolorization and mineralization of C.I. acid yellow 23 by fenton and photo-fenton processes. Dyes Pigments, 73: 305-310. DOI: 10.1016/j.dyepig.2006.01.002

Montano, J., 2007. Combination of advanced oxidation processes and biological treatments for commercial reactive azo dyes removal. University of Barcelona.

Munter, R., 2001. Advanced oxidation processes current status and prospects. Proc. Estonian Acad. Sci. Chem., 50: 59-80.

Muruganandham, M. and M. Swaminathan, 2004. Photochemical oxidation of reactive azo dye with UV-H2O2 process. Dyes Pigments, 62: 269-275. DOI: 10.1016/j.dyepig.2003.12.006

Neamtu, M., A. Yediler, L. Siminiceanu and A. Kettrup, 2003. Oxidation of commercial reactive azo dye aqueous solutions by the photo-Fenton and Fenton-like processes. J. Photochem. Photobiol. A:Chem., 161: 87-93. DOI: 10.1016/S1010-6030(03)00270-3
Nese, T., N. Sivri and I. Toroz, 2007. Pollutants of textile industry wastewater and assessment of its discharge limits by water quality standards. Turkish J. Fisheries Aquatic Sci., 7: 97-103.

Ozkan, A., M. Ozkan, R. Gurkan, M. Akcay and M. Sokmenm, 2004. Photocatalytic degradation of a textile azo dye, Sirius Gelb GC on $\mathrm{TiO} 2$ or Ag-TiO2 particles in the absence and presence of UV irradiation: the effects of some inorganic anions on the photocatalysis. Photochem. Photobiol. A: Chem., 163: 29-35. DOI: 10.1016/S1010-6030(03)00426-X,

Perkowski, J. and L. Kos, 2003. Decolouration of Model Dye House Wastewater with Advanced Oxidation Processes. Fibres Textiles Eastern Eur., 11: 67-71.

Rodriguez, M., 2003. Fenton and UV-vis Based advanced oxidation processes in wastewater treatment: Degradation, mineralization and biodegradability enhancement. University of Barcelona.

Saien, J. and A. Soleymani, 2007. Degradation and mineralization of direct blue 71 in a circulating upflow reactor by $\mathrm{UV} / \mathrm{TiO}_{2}$ process and employing a new method in kinetic study. Hazardous Materials 144: 506-512. PMID: 17134827

SET, 2012. Advanced Oxidation Ozone UV Processes. Spartan Environmental Technologies.

Shu, H. and M. Chang, 2005. Decolorization effects of six azo dyes by $\mathrm{O}_{3}, \mathrm{UV} / \mathrm{O}_{3}$ and $\mathrm{UV} / \mathrm{H}_{2} \mathrm{O}_{2}$ processes. Dyes Pigments, 65: 25-31. DOI: 10.1016/j.dyepig.2004.06.014

Shu, H. and W. Hsieh, 2006. Treatment of dye manufacturing plant effluent using an annular UV/H2O2 reactor with multi-UV lamps. Separation Purificat. Technol., 51: 379-386. DOI: 10.1016/j.seppur.2006.03.001

Soutsas, K., V. Karayannis, I. Poulios, A. Riga and K. Ntampefliotis et al., 2010. Decolorization and degradation of reactive azo dyes via heterogeneous photocatalytic processes. Desalination, 250: 345-350. DOI: 10.1016/j.desal.2009.09.054

Stasinakis, A., 2008. Use if selected advances oxidation processes (aops) for wastewater treatment - A mini review. Global Nest., 10: 376-385.

Verma, M. and A. Ghaly, 2008. Treatment of remazol brilliant blue dye effluents by advanced photo oxidation process in $\mathrm{TiO}_{2} / \mathrm{UV}$ and $\mathrm{H}_{2} \mathrm{O}_{2} / \mathrm{UV}$ reactors. Am. J. Eng. Applied Sci., 1: 230-240. DOI: 10.3844/ajeassp.2008.230.240 
Rishi Ananthashankar and Abdel Ghaly / American Journal of Environmental Science 9 (4): 322-333, 2013

Vinitnantharat, S., W. Chartthe and A. Pinitwakul, 2003. Toxicity of reactive red 141 and basic 14 to algae and waterflea. Division Enviro. Technol.

White, R., 2011. 6274, Dalhousie University, Coburg Road, Room 212, Chemistry Building.
Yang, Y., D. Wyatt and M. Bahorsky, 1998. Decolorization of dyes using $\mathrm{UV} / \mathrm{H}_{2} \mathrm{O}_{2}$ photochemical oxidation. Textile Chemist Colorist, 30: 27-35. 